\title{
REKONSTRUKSI PENDIDIKAN SURAU DI MINANGKABAU (Tinjauan Analisis Psikologi Sosial)
}

\author{
Oleh: Afrinaldi*
}

\begin{abstract}
:
This paper aims at portraying the educational process in surau in the past and explaining basic differences the process at present time. This study tries to reveal the urgency of reviving the main role of surau as the center of knowledge development and shifting the present traditional paradigm of surau from the place for worshiping, reciting Holy Quran, and Islamic teaching toward the center for data and information which in turn the center for knowledge development. Historically, the role of surau in the past was successful to produce qualified spiritual role figures. In contrast, surau, as the asset of nagari at present time, seemingly does not interest young generation. This article therefore tries to present some innovative ideas in reviving and developing educational system in surau through sociopsychological approach.
\end{abstract}

Kata kunci: analisis, pendidikan surau, psikologi sosial

\section{PENDAHULUAN}

$\mathrm{M}$ asyarakat Minangkabau sangat menjunjung tinggi nilai-nilai adat dan budaya sebagaimana yang tertuang dalam "Piagam Marapalam": "Adat Basandi Sarak, Syarak Basandi Kitabullah". Keinginan untuk menghayati dan mengamalkan adat secara murni dan konsekwen menjadi pegangan dalam kehidupan bermasyarakat di Ranah Minang. Hal ini juga dipertegas oleh "patatah patitiah" yang mengatakan "tasindorong jajak manurun, tatukiak jajak mandaki, adat jo syarak kok tasusun, bumi sanang padi manjadi", artinya antara misi yang disampaikan oleh agama sejalan dengan adat istiadat yang berlaku di Ranah Minang. Sehingga relevansi pendidikan agama dengan adat tidak bisa dipisahkan dalam kehidupan bermasyarakat di Minangkabau.

\section{PEMBAHASAN}

\section{Realitas Sejarah, Surau Sebagai Lembaga Pendidikan Pertama}

Ada dua pendapat yang bisa dipegang tentang kapan masuknya Islam ke Minangkabau, pertama pendapat Hamka yang menyatakan Islam telah masuk ke Minangkabau sekitar abad ke 7 Masehi. Pendapat Hamka ini, bisa dikuatkan melalui sejarah perdagangan orang Arab ke berbagai belahan dunia. Khusus, masalah masuknya Islam awal ke Minangkabau. Imam Maulana, dalam Silfina Hanani (2007:52) menceritakan dalam catatan sejarah klasik Mubalighul

* Penulis adalah Dosen Psikologi Sekolah Tinggi Agama Islam Negeri (STAIN) Bukittinggi 
Islam disebutkan pada dasarnya Islam telah masuk ke Minangkabau pada tahun $580 \mathrm{H}$. Masuknya Islam ini diawali dari sejarah terdamparnya saudagar Arab di perairan Minangkabau, yang kemudian menemukan perkampungan penduduk. Sudagar itu bernama Saidi Abdullah. Mereka diterima oleh penduduk dan sebagai anggota masyarakat. Melalui Saidi Abdullah ini pula Islam diperkenalkan kepada keluarga yang menerimanya. Kemudian kawin dengan putri kepala dusun yang konon kepala dusun tersebut berasal dari keturunan Raja Pagaruyung. Dusun yang dihuni dan sekaligus sebagai tempat penyebaran Islam itu adalah kampung durian yang terletak dipinggir kota Padang Sebelah Timur. Namun, setelah Saidi Abdullah meninggal, maka terjadi kekosongan-kekosongan penyebaran Islam, bahkan masyarakat kembali kepada agama lamanya.

Sementara itu ada yang menyebutkan pada abad ke 13 seiring dengan penguniversalan masuknya Islam di $\mathrm{Nu}$ santara dengan berdirinya kerajaan Samudara Pasai. Namun, perkembangan Islam di Minangkabau selanjutnya ditandai dengan diperintahnya kerajaan Pagaruyung oleh Raja Sultan Alif yang beragama Islam pada abad 16 .

Perkembangan Islam pada masa awal, kajian sejarah lebih terfokus pada peran Burhanuddin, setelah ia kembali menuntut ilmu bersama seorang guru di Aceh yang bernama Alkalani Amin bin Abd Rauf Singkil Al Jawi bin Alfansyuri. Kehadirian Burhanuddin, pada masa awal ini disebut-sebut sebagai peletak dasar Islam di Minangkabau, namun jika menilik pada alur sejarah, sebelum itu Islam sudah hadir di Minangkabau tetapi akibat tidak adanya survivalisme maka agama Islam dalam pengamalan masyarakat Minangkabau mengalami pasang surut.

Burhanuddin dengan pendidikan Suraunya, telah mengembangkan tradisi ke Islamam. Murid-murid yang telah selesai belajar di Surau Burhanuddin, juga mendirikan Surau di tempat lain atau di kampung halamnnya, transmisi dan diffusi agama ketika ini kuat dilakukan oleh murid-murid Buhanuddin. Oleh sebab itu revivalisme ajaran seorang ulama menyebar dan muridmuridnya sangat fanatik terhadap ajaran gurunya (Silfia Hanani, 2008:53).

Pada masa sekarang, surau sangat identik dengan ulama. Ulama melangsungkan pendidikan dan membentuk jemaah di surau. Bentuk pendidikan yang dilangsungkan sederhana. Namun, dalam catatan sejarah pendidikan di Minangkabau, pendidikan surau belum terlihat diklasifikasikan seperti halnya perkembangan pondok pesantren di Jawa. Soedjoko Prasodjo dalam Kuntowidjoyo, 1999:251) mengatakan bahwa ada lima pola pesantren mulai dari sederhana sampai pada yang modern. Lima pola itu adalah Pola I; pesantren terdiri hanya dari masjid dan rumah kiyai. Pola II terdiri dari masjid, rumah kiyai dan pondok. Pola III, terdiri dari masjid, rumah kiyai dan madrsah. Pola IV, yakni masjid, rumah kiyai, pondok, madrasah dan tempat keterampilan. Pola V yakni masjid, rumah kiyai, pondok, madrsah, tempat keterampilan, universitas, gedung pertemuan, tempat olah raga dan sekolah umum.

Pendidikan Surau Burhanuddin sama dengan pola surau besar (masjidpondok), rumah kiyai dan surau kecil (tempat keterampilan dan penginapan). Surau besar, bisanya surau tempat berlangsungnya pendidikan secara bersama, ulama mengajar disini, ia sekaligus pemilik surau. Sedangkan surau kecil yakni, tempat tinggal santri. Di surau kecil ini berlangsung juga pendidikan, dimana murid yang senior mengajarkan murid yunior atas persetujuan ulama (guru). Di surau kecil ini santri tingal sehari-hari dan di surau kecil ini pula murid me- 
lakukan berbagai aktivitas untuk mematangkan dirinya (Silfia Hanani, 2007: 53). Di surau inilah anak-anak Minang bermula mengenal kehidupan sosial dengan menyaksikan langsung bagaimana kehidupan para ulama dan santri Surau mengenal prilaku satu individu dengan individu yang lainnya, yang dalam kajian psikologi sosial meliputi bidangbidang interaksi sosial, prasangka sosial, persepsi sosial, kelompok sosial, kerumunan sosial, pembentukan sikap (attitude) dan lain sebagainya.

Fakta sosial ini juga yang telah dijadikan modal oleh anak-anak Minang dalam berkomunikasi dan bersosialisasi di tengah masyarakat pasca mereka keluar dari surau yang sering diidentikkan dengan istilah pergi merantau. Sehingga kejayaan Minangkabau pada masa silam tidak bisa dilepaskan dari perannya para ulama sebagai role play dalam mensosialisasikan betapa pentingnya ilmu pengetahuan dan kaitannya dengan agama dalam mempertahankan idealisme masyarakat Minang sebagai orang terpelajar yang mempuyai peradaban (civilization).

Kondisi sosial masyarakat pada masa dulu telah meyakinkan ulama untuk secepatnya melakukan social action (dakwah bil hal) untuk melakukan reformasi akidah dengan mengaplikasikan ilmu pengetahuan dengan metode culture approach secara face to face kepada tokoh-tokoh adat melalui sarana pendidikan surau sebagaimana yang dikutip oleh Amir Syarifuddin (2004) dalam sebuah artikel yang berjudul Pokok-pokok Pikiran Islam dan Intelektual Minangkabau mengatakan bahwa dulu di Minang kabau "Lembaga pendidikan agama pertama di wilayah adat Minangkabau adalah"surau".

Karakteristik surau adalah suatu tempat pendidikan dan sekaligus tempat tinggal murid dan guru, sehingga memungkinkan keberadaan murid bersama guru dalam waktu relatif lebih panjang, dalam waktu terjadinya transformasi ilmu pengetahuan dan pengalaman guru kepada murid. Dengan cara ini regenerasi ulama berlangsung secara alamiyah. Surau dikenal sebagai lembaga pendidikan agama pertama di wilayah Minangkabau adalah surau Syekh Burhanuddin di Ulakan Pariaman didirikan sekitar abad ke17. Surau ini didatangi oleh murid-murid dari berbagai pelosok Minangkabau, yang pada gilirannya setelah murid itu kembali kenegerinya juga mendirikan surau pula. Selanjutnya bermunculan surau-surau di wilayah ini. "Kembali ke nagari, kembali ke surau" (Back to nagari, back to surau), dari tinjauan sosiologis, nagari merupakan konsep kosmologis yang di dalamnya terkandung kehidupan religius yang bersifat kontemplatif transenden. Secara holistik, dalam nagari tidak saja diurus masalah teknis pemerintahan, malahan sampai pada hal-hal yang bersifat transenden seperti kehidupan surau. Karena itu, bersamaan dengan dicanangkannya kembali kepemerintahan nagari di Sumatera Barat (Sumbar), sekaligus juga dicanangkan kembali ke surau.

Tokoh-tokoh besar yang dilahirkan dari Ranah Minang, diantaranya ialah: Syekh Ahmad Khatib Al-Minangkabawi, H. Miskin, H. Piobang, H. Sumanik, Tan Malaka, Imam Bonjol, Sjech M. Djamil Djambek, Tuangku Rao, Sjech Ibrahim Musa, M. Hatta, HAMKA, Syahrir, M. Natsir, M. Yunus, Agus Salim, Rahmah El Yunusiah, ini hanya sebahagian kecil dari tokoh dan pejuang Minang dan masih banyak lagi tokoh-tokoh lain yang belum sempat tercatat dalam sejarah yang juga telah ikut berjasa kepada bangsa, negara dan agama. Dalam sejarahnya semua tokoh ini mengawali pendidikannya di surau sebagai pengembangan kepribadian dan pembelajaran sosial. 
Tokoh-tokoh ini jugalah pada dasarnya yang telah mengharumkan nama Minangkabau sebagai masyarakat intelek, religius dan beradat Namun citacita mulia para tokoh ini sekarang sudah mulai lupus dari peradaban. Istilah "Tak lakang dek paneh, tak lapuak dek hujan" hanyalah tinggal kenangan indah dalam masyarakat Minang sekarang. Hilangnya jati diri (idealisme) sebagai orang Minang ketika sebuah peradaban (Civilization) telah berubah menjadi sebuah kegoncangan budaya (culture lag), hal ini sangat nyata kita saksikan di lapangan, ketika benturan budaya dan agama itu sudah tidak terelakkan lagi, maka tentu akan berimplikasi kepada jiwa, kepribadian dan paradigma berfikir generasi Minang sekarang. Sehingga muncullah budaya westernisasi sebagai apresiasi dari kebebasan mitos demokrasi yang menyesatkan (Amir M.S, 2003).

Hamka (1984) mengatakan bahwa syarak mengata, adat memakai, maksudnya Al-Quran, Sunnah, Fiqh, lalu dipakai menurut adat. Kata "Syarak" mungkin bisa kita interpretasikan ke dalam dua kategori: pertama Adat "Syarak'iah" maksudnya orang yang betul-betul menjalankan adat-istiadat sesuai dengan ayat-ayat Al-Quran. Kedua: Adat "Jahiliah" maksudnya orang yang mengamalkan adat istiadat yang bertentangan dengan agama Islam. Sebagai contoh tradisi membagi-bagikan uang ketika waktu hari ke tiga setelah kematian dari pihak keluarga yang sedang berduka (studi kasus di Pariaman), secara "syar' $i$ " orang yang kemalangan dari kematian harus dikunjungi untuk menghibur (Takziah), artinya orang yang mengunjungilah yang diharuskan membawa makanan untuk menghibur keluarga yang sedang berduka. Persoalan yang terjadi sekarang justru sebaliknya, prinsip ini tentulah sangat bertentangan sekali dengan agama. Mungkin inilah salah satu fenomena sosial keagamaan yang perlu kita cermati untuk dikritisi agar kemurnian (puritanime) Islam dari pada tahayul, bid'ah dan kurafat dapat terpelihara.

\section{Realitas Masa Kini, Surau Berganti Fungsi}

Historisasi surau tidak dapat dilepaskan dari masyarakat pedesaan, karena surau pada awalnya dibangun pada kawasan pedesaan dalam rangka spritualisasi manusia yang mempercayai adanya kekuatan gaib di luar dirinya. Perluasan fungsi surau dari segi religius ini mendapat dukungan dari penguasa, sehingga surau berkembang di kota.

Perkembangan surau dalam dua komunitas (desa dan kota) jelas menunjukkan perbedaan-perbedaan, tidak saja dari segi fungsinya tetapi juga dalam memanifestasikan surau tersebut. Pada masyarakat pedesaan dengan ciri khas masyarakatnya yang homogen dan tradisional, jelas berbeda dalam memanifestasikan surau dengan masyarakat perkotaan yang hetorogen (silfia Hanani, 2002: 72).

Menurut hemat penulis, secara fisik surau tidak mengalami kemunduran, hal ini dapat disaksikan betapa banyak masjid/mushalla megah berdiri di seluruh Sumbar. Namun dalam aplikasinya surau tidak lagi berfungsi sebagai wahana pendidikan multifugsi seperti dulu. Surau hanya terkesan sebagai tempat belajar Al-quran/iqra'. Karena ada anggapan bahwa surau hanya boleh digunakan untuk kegiatan ibadah ritual. Hal ini juga dipengaruhi oleh berkembangnya lembaga formal pendidikan agama sebagai tempat menimba ilmu pengetahuan. Tradisi "duduak samo randah badiri samo tagak" dalam keadaan bersila dan bersimpuh menuntut ilmu di pondok pesantren dan surau sudah berubah dengan pakai kursi dan meja di sekolah-sekolah agama dan perguruan tinggi agama, Kemudian ber- 
dirinya Lembaga Kerapatan Adat Alam Minangkabau (LKAAM) sebagai sarana pendidikan dan keterampilan dalam pelestarian adat dan budaya. Di sinilah asal muasal terjadinya pemisahan multifungsi surau sebagai lembaga pendidikan, yang pada gilirannya berdampak kepada stagnan berfikir sehingga menyebabkan mutu pendidikan merosot.

Untuk mengembalikan orang $\mathrm{Mi}$ nang kepada khittahnya semula sebagai orang intelek yang berbudaya dan religius, maka perlu upaya nyata oleh semua lapisan dengan semangat "barek samo dipikua, ringan samo dijinjiang" (Suharman dkk, 2000) untuk menjaga identitas sebagai masyarakat yang beradab, karena peradabanlah orang bisa dikenang, sehingga cita-cita mulia untuk merekonstruksi "Mabangkik Batang Tarandam" yang sudah mengancam regenerasi kepemimpinan dapat terwujud lagi di Ranah Minang yang kita cintai ini. Sehingga kehadiran sebuah masyarakat "Madaniyyah" yang digaunggaungkan selama ini akan menjadi sebuah kenyataan, sebuah negeri yang "Baldatun tayyibaatuun wa rabbun ghafuur".

\section{Rekonstruksi Pendidikan Surau dengan Pendekatan Psikologi Sosial.}

Pendidikan Surau merupakan tradisi turun temurun dalam pola pendidikan generasi Minang tempo dulu sampai sekarang. Jika ditinjau dalam kajian psikologi sosial dinamika tadisi surau yang dikembangkan para tokoh dulu itu sangat sejalan dengan teori lapangan (field theory) yang digagas oleh seorang psikolog, Kurt Lewin dalam Sarlito Wirawan, (2003), pada tahun 1935,1936 mengkaji perilaku sosial melalui pendekatan konsep "medan"/"field" atau "ruang kehidupan" -life space. Untuk memahami konsep ini perlu dipahami bahwa secara tradisional para psikolog memfokuskan pada keyakinan bahwa karakter individual (instink dan kebiasaan), bebas - lepas dari pengaruh situasi di mana individu melakukan aktivitas. Namun Lewin kurang sepaham dengan keyakinan tersebut. Menurutnya penjelasan tentang perilaku yang tidak memperhitungkan faktor situasi, tidaklah lengkap.

Lewin merasa bahwa semua peristiwa psikologis apakah itu berupa tindakan, pikiran, impian, harapan, atau apapun, kesemuanya itu merupakan fungsi dari "ruang kehidupan"- individu dan lingkungan dipandang sebagai sebuah konstelasi yang saling tergantung satu sama lainnya. Artinya "ruang kehidupan" merupakan determinan bagi tindakan, impian, harapan, pikiran seseorang. Lewin memaknakan "ruang kehidupan" sebagai seluruh peristiwa (masa lampau, sekarang, masa datang) yang berpengaruh pada perilaku dalam satu situasi tertentu.

Bagi Lewin, pemahaman atas perilaku seseorang senantiasa harus dikaitkan dengan konteks - lingkungan di mana perilaku tertentu ditampilkan. Intinya, teori medan berupaya menguraikan bagaimana situasi yang ada (field) di sekeliling individu bepengaruh pada perilakunya. Sesungguhnya teori medan mirip dengan konsep "gestalt" dalam psikologi yang memandang bahwa eksistensi bagian-bagian atau unsur-unsur tidak bisa terlepas satu sama lainnya (http://Hasan Mustafa.blogspot.com, 4/8/ 2009). Lebih lanjut Kurl Lewin juga mengibaratkan kehidupan di dunia ini sebagai keadaan tingkah laku yang sering ditentukan oleh ruang kehidupan yang merupakan hasil interaksi antara individu dengan lingkungan (James A, 1986:57). Untuk menjemput kembali tradisi pendidikan ala surau itu ada beberapa langkah yang mesti dibudayakan oleh masyarakat Minangkabau secara bertahap: 


\section{Melalui Motivasi Membaca}

Minat baca yang rendah di kalangan anak nagari sekarang telah mempengaruhi rendahnya kualitas sumber daya manusia. Rendahnya minat baca tersebut, bukan berarti guru dan orang tua tidak memotivasi untuk membaca. Motivasi yang dilakukan hanya dengan menyuruh, tapi tidak dengan mencontohnya atau memberikan buku-buku yang dapat dibaca oleh anak-anak. Padahal untuk memotivasi membaca, sangat diperlukan bahan bacaan, sementara bahan bacaan itu tidak tersedia di hadapan anak-anak. Motivasi membaca dalam bentuk menyuruh tanpa ada buku dan percontohan tidak akan berhasil dalam membangunkan minat baca anak. Apalagi anak-anak sekarang lebih dominan menonton televisi daripada membaca.

Buku sebagai fasilitas minat baca tidak menjadi bahan perhatian penting bagi pihak sekolah, masyarakat, pemerintah, dan orang tua. Kebiasaan yang menganggap tidak begitu penting inilah yang telah mempengaruhi anak nagari tidak membudayakan dalam hidupnya berusaha mendapatkan bahan bacaan dengan cara meminjam ke tempat lain atau membelinya dengan menyisihkan uang pemberian orang tua mereka. Anak nagari tidak terbiasa membeli bahan bacaan, sehingga buku sebagai bahan bacaan betul-betul sangat terbatas diperoleh oleh anak-anak nagari. Anak nagari satu kali dalam satu bulan pun tidak terbiasa mengusahakan satu bahan bacaan untuk dibacanya, hal ini dapat dilihat dari hasil penelitian Silfia Hanani, dkk didapati $93 \%$ anak nagari tidak pernah perbulannya mendapatkan bahan bacaan. Artinya mereka sudah terbiasa dengan bacaan-bacaan buku-buku yang tidak berbeda (Silfia Hamdani, 2008:69).

Anak nagari, kesulitan mengakses atau mendapatkan buku sebagai bahan bacaannya. Motivasi membaca anak dilakukan guru dan orang tua tidak diikuti oleh perlengkapan buku atau bahan bacaan sehingga anak tidak terbiasa dengan buku. Untuk itu, masjid atau surau sangat mempunyai peranan penting dalam mengatasi masalah ini jika diberdayakan sebagai tempat serambi baca dan pusat penggalian ilmu pengetahuan bagi anak nagari.

\section{Merobah Tradisi Simbolisasi Iqra'}

Tidak ada tanda-tanda yang menunjukkan perubahan peranan masjid dan surau setelah kembali pada pemerintahan nagari dan menghangatnya gerakan kembali ke surau. Masjid dan surau tetap memainkan peranan seperti biasanya, yaitu sebagai tempat shalat. Tidak ada yang berubah dari fungsi aslinya.

Orang tua-tua tetap menjadi pengunjung masjid yang dominan untuk melaksanakan shalat lima waktu berjemaah. Tidak terlalu ramai pula, paling banyak setiap hari paling banyak ada sepuluh orang jemaah shalat tersebut. Kembali ke surau tidak ada makna perubahan yang signifikan pada dari hari ke hari.

Pemerintahan nagari pun tidak banyak ambil andil dalam Program Kembali Surau. Surau atau masjid yang ada dalam nagari lebih dominan menjadi simbol religiusitas nagari, karena Surau atau masjid merupakan salah satu persyaratan bagi sebuah nagari dan menurut undang-undang nagari tidak akan dapat nagari berdiri tanpa ada surau atau masjid dalam nagari tersebut.

Perkembangan jumlah penduduk, telah mendorong lahirnya masjid-masjid baru untuk kegiatan agama di nagari. Sementara surau-surau yang ada dibiarkan dan tidak diaktualisasikan dan bahkan dengan kehadiran masjid, surau-surau yang ada tertinggalkan dari rutinitasnya.

Surau Haji Bahroen yang berdiri di sebelah Masjid raya di Koto Gadang, sebelum gempa bumi yang menjadi simbol 
dan tidak dipergunakan sebagai tempat ibadah dan belajar agama. Pada hal surau ini merupakan tempat belajar agama yang monumental bagi anak Nagari Koto Gadang sebelum kemerdekaan. Namun, setelah berdirinya masjid di samping surau ini, keberadaan surau Haji Bahroen hanya menjadi monumen.

Sementara masjid-masjid yang ada tidak dibenahi dan direkapitulasikan sebagaimana rumah ibadah yang dapat menjembatani permasalahan pendidikan anak nagari, karena Masjid sebagai milik umum sangat berpotensi untuk dikembangkan menjadi sarana yang dapat mengatasi masalah minat baca. Keterbelekangan kegiatan masjid atau surau dari kegiatan yang dapat memberdayakan sumber daya manusia ini.

Ada beberapa permasalahan yang menyebabkan Masjid atau Surau kondisinya tidak dapat menjembatani permasalahan umatnya, termasuk dalam menjembatani masalah minat baca.

\section{Merobah Pola Pikir Masyarakat dari Pemaknaan Institusi yang Sempit}

Masjid atau surau telah disepakati oleh masyarakat nagari sebagai institusi agama. Pengertian istititusi agama untuk masjid dan Surau berada dalam pengertian yang sempit. Diartikan oleh masyarakat sebagai institusi sembahyang dan kegiatan cermah agama.

Tua-tua kampung nagari dan kaum muda pun berfikiran seperti itu. Masjid baginya hanya sebagai tempat ibadah mahdhah dan tidak menempatkan masjid sebagai isntitusi yang dapat menjadi pengelola ekonomi, pendidikan, dan sebagainya.

Akibat dari penempatan masjid dan surau seperti itu maka rumah ibadah ini tidak dikembangkan dengan kegiatan-kegiatan yang diperlukan oleh umat. Dalam era kejayaan Islam, masjid merupakan basis kebudayaan dan ilmu pengetahuan. Pada era kejayaan Islam di Cardova misalnya, masjid dijadikan se- bagai pusat ilmu pengetahuan yang mempunyai perpustakaan.

Di Nagari Koto Gadang, walaupun sudah terkenal sebagai nagari yang mempunyai kesejahteraan masyarakat yang baik dan mempunyai banyak orang cerdik pandai, pemaknaan masjid dan surau masih dalam institusi yang sempit tersebut, sehingga rumah ibadah tidak satu pun yang memiliki perpustakaan.

\section{Pengelolaan Surau Secara Moderen}

Masjid atau surau tidak mempunyai pengelolaan yang teratur. Pengeloalannya dilakukan oleh pengurus Masjid. Pengelolaan ini lebih dominan tertumpu pada pembangunan fisik masjid atau surau, sehingga masing-masing rumah ibadah terlihat berdiri dengan megah, terutama masjid yang ada pada masing-masing jorong. Setiap masjid disetiap jorong baik yang ada di Nagari Koto Gadang maupun di nagari Pariangan semuanya mempunyai bangunan yang megah. Bahkan nagari Koto Gadang akan mempunyai sebuah masjid yang berasitektur modern, jika masjid yang runtuh akibat gempa tahun 2007 pembangunannya selesai.

Di Pariangan sebagai nagari agraris, kehidupan masyarakat pada umumnya banyak bertani, pada masing-masing nagari mempunyai bagunan Masjid yang modern, kecuali Masjid tua yang terdapat di jorong Pariangan. Bangunannya dipertahankan dengan arsitek Masjid masa lalu dengan gonjong yang bertingkat-tingkat.

Masjid-masjid yang megah ini didalamnya hanya ada ruangan lepas untuk shalat. Tidak ditemukan ruangan untuk penyimpanan buku atau ruang perpustakaan. Hanya ada almari untuk menyimpan al-Quran. Tidak ada tandatanda adanya masjid dijadikan sebagai tempat untuk peminjaman buku yang memfasilitasi permasalahan minimnya bahan bacaan bagi anak nagari. Pada hal anak nagari sangat berharap masjid 
mempunyai perpustakaan dan mempunyai keyakinan jika masjid di sekitarnya dapat memotivasi membaca. Sebanyak $70 \%$ anak nagari sangat berkeyakinan keberadaan perpustakaan masjid dapat mengatasi minat baca yang rendah, karena minat baca yang rendah tersebut dipengaruhi oleh minimnya bahan bacaan tersedia di nagari. Sementara masingmasing $15 \%$ mempunyai pendapat bahwa keberadaan perpustakaan masjid tidak dapat mengatasi masalah minat baca tersebut dan bahkan tidak tahu sama sekali.

\section{KESIMPULAN}

Dapat dipahami bahwa kehadiran surau di Minangkabau telah banyak memberikan pencerahan dan penegakan moral dan martabat masyarakat Minangkabau. Seiring dengan itu peran dan fungsi surau juga sangat mempunyai kedudukan yang tak terpisahkan dalam berdirinya sebuah nagari. Dulu kehidupan sosial anak nagari selalu dibentuk dari

\section{DAFTAR RUJUKAN}

Amir M.S, 2003. Adat Minangkabau Pola dan Tujuan Hidup Orang Minang, Jakarta: Mutiara Sumber Widya

Duski Samad, 2002. Syekh Burhanuddin dan Islamisasi Minangkabau (syarak Mandaki Adat Manurun), Jakarta: The Minangkabau Foundation

Hamka, 1984. Islam dan Adat Minangkabau, Jakarta: Pustaka Panjimas

Hasan Mustafa, Perspektif dalam Psikologi Sosial,

http://hasanmustafa.blogspot.com/2009/ 08/prespektif-psikologi- pendidikan surau yang selalu mengajarkan pola interakasi sosial, komunikasi sosial, persepsi sosial, kerumunan sosial, motivasi dan lain sebagainya, sehingga semua materi psikologi sosial ini selalu menjadi garis pandu dalam membentuk karakter dan kepribadian anak nagari untuk membekali dirinya baik dalam kehidupan bernagari atau di luar nagari (pergi merantau).

Pada akhirnya keberadaan surau di zaman dulu dan kehidupan sekarang bergeser fungsi dan peranannya, karena pola pikir dan persepsi masing-masing generasi sudah tidak sama pandangan dalam mengisi kegitan surau. Makanya kehidupan surau masih seperti itu-itu juga sampai hari ini, penghuninya tetap saja didominasi oleh kaum tua yang secara fisik sudah tidak produktif lagi. Akibatnya anak-anak nagari tidak tertarik dengan kehidupan surau yang tidak banyak menawarkan pendidikan-pendidikan berbobot dan berkualitas seperti: perpustakaan surau sebagai pusat ilmu pengetahuan dan peradaban.

sosial.html, Akses data tanggal: 4/8/2009.

http://www.isnet.org/archivemilis/archive97/feb97/0033.html

Access date: 24-2-2005

http://www.cimbuak.net/content/view/77 154/ Access date: 24-2-2005

http://psikologisosial/sociallearning.html Access date 24-2-2005

Idrus Hakimi Dt. Rajo penghulu, 1994. Pancasila dan Adat Minangkabau Basandi Syarak di Sumatera Barat, Padang: LKAAM Sumbar

James A. Schllenberg yang diterjemahkan oleh Mohammad Haji Yusuf, 1986. Tokoh-tokoh 
Psikologi Sosial, Bangi: Universiti Kebangsaan Malaysia.

Sarlito Wirawan Sarwono, 2003. Teoriteori Psikologi Sosial, Jakarta: Raja Grafindo Persada.

Silfia Hanani, 2002. Surau Aset Lokal yang Tercecer, Bandung: Humaira.

-------, 2007. Revitaslisasi Pemikiran Ulama Nusantara, (Karyanet, Dewan Bahasa dan Pustaka Malaysia.

-------, dkk. 2008. Meningkatkan Minat Baca Anak Nagari Melalui Pemberdayaan Masjid Sebagai

Indeks

analisis, 44

masyarakat, 193, 194, 195, 196, 197, 198, 199

pendidikan, 44, 193, 194, 196, 197, 198, 199
Serambi Baca (Studi Kasus: Implementasi Gerakan Kembali Ke Surau dalam Nagari di Sumatera Barat Sebagai Peningkatan Kualitas Sumber Daya Manusia). Laporan Penelitian Kelompok P3M STAIN Bukittinggi.

Siti Nadroh, 1999. Wacana Keagamaan dan Politik Nurcholish Madjid, Jakarta: Rajawali Grafindo Persada

Suarman dkk, 2000. Adat Minangkabau Nan Salingka Hiduik, Padang: Duta Utama

psikologi, 44, 194, 196, 197, 199

sosial, 44, 194, 195, 196, 199

surau, 44, 193, 194, 195, 196, 197, 198, 199 